\title{
Comparison of Diagnostic Performance of Preoperative PET-CT for Patients with and without Neoadjuvant Therapy in Non-Small Cell Lung Cancer: Does Induction Therapy Affect the Preoperative PET-CT Results?
}

\author{
Soner GURSOY ${ }^{1}$, Ahmet UCVET ${ }^{1}$, Ahmet E. ERBAYCU ${ }^{2}$, Esra YAMANSAVCI ${ }^{1}$, \\ Hakan KOPARAL ${ }^{3}$, Engin OZBILEK ${ }^{3}$, Seyda O. KAYA ${ }^{1}$
}

\begin{abstract}
${ }^{1}$ Dr Suat Seren Chest Diseases and Thoracic Surgery Training Hospital, Department of Thoracic Surgery
${ }^{2}$ Dr Suat Seren Chest Diseases and Thoracic Surgery Training Hospital, Department of Pulmonary Diseases
\end{abstract} ${ }^{3}$ Dr Suat Seren Chest Diseases and Thoracic Surgery Training Hospital, Department of Nuclear Medicine, Izmir, TURKEY

\begin{abstract}
PET-CT has been widely used for restaging after induction therapy in patients with non-small cell lung carcinoma. We aimed to assess the role of preoperative PET-CT in patients receiving induction therapy and compare with those without induction therapy. Patients treated with surgery for non-small cell lung carcinoma were included. There were two subgroups according to the presence of preoperative induction therapy. The results of preoperative PET-CT in these two groups were compared. There were 217 patients, 58 in neoadjuvant group and 159 in control (without preoperative induction therapy) group. In N2 lymph nodes, the positive predictive value (PPV) was significantly higher in the neoadjuvant group than in the control group $(p=0.01)$, where the negative predictive value (NPV) ( $p=0.0001)$ and accuracy $(p=0.03)$ were significantly lower. In aorticopulmonary lymph nodes, the NPV was significantly higher in the control group ( $p=0.002)$. In lower N2 lymph nodes, the PPV was higher $(p=0.007)$ and the NPV was lower $(p=0.003)$ in the neoadjuvant group. In N1 lymph nodes, the specificity was found to be lower in the neoadjuvant group ( $p=0.01)$. The sensitivity, PPV and accuracy for mass was lower in the neoadjuvant group ( $p=0.002, p=0.0003$, and $p=0.001$, respectively).

The negative predictive value and accuracy of PET-CT were slightly decreased in patients with non-small cell lung carcinoma received induction therapy before surgical resection. PET-CT appears to be beneficial for the assessment of patients those are planned to be treated surgically for lung cancer whether they have received induction therapy or not.
\end{abstract}

Keywords: Non-small cell lung cancer, Positron emission tomography, Lung cancer, Surgery, Restaging 
Küçük Hücreli Dışı Akciğer Karsinomlu Neoadjuvan Tedavi Alan ve Almayan Hastalarda Preoperatif PET-BT'nin Tanısal Performansının Karşılaştırııması: İndüksiyon Tedavisi Preoperatif PET-BT Sonuçlarını Etkiliyor mu?

PET-BT küçük hücreli dışı akciğer karsinomlu hastalarda indüksiyon tedavisi sonrası yeniden evrelemede yaygın olarak kullanılmaktadır. Preoperatif PET-BT'nin indüksiyon tedavisi alan hastalardaki rolünü araştırmayı ve tedavi almayanlar ile karşılaştırmayı amaçladık. Küçük hücreli dışı akciğer karsinomu nedeniyle cerrahi olarak tedavi edilen hastalar çalışmaya alındı. Preoperatif indüksiyon tedavisi varlığına göre iki subgrup oluşturuldu. Bu iki grup arasında preoperative PET-BT sonuçları karşılaştırıldı. Neoadjuvan grubunda 58 ve kontrol (preoperatif indüksiyon tedavisi almayan) grupta 159, toplam 217 hasta alındı. N2 lenf nodlarında, pozitif prediktif değer (PPV) neoadjuvan grupta kontrol grubuna göre anlamlı şekilde yüksek ( $p=0,01)$, negatif prediktif değer (NPV) ( $p=0.0001)$ ve doğruluk ( $p=0.03$ ) düşük idi. Aortikopulmoner lenf nodlarında, kontrol grubunda NPV anlamlı şekilde yüksek idi ( $p=0.002)$. Alt N2 lenf nodlarında, neoadjuvan grubunda PPV yüksek ( $p=0.007)$ ve NPV düşük $(p=0.003)$ idi. N1 lenf nodlarında, neoadjuvan grubunda spesifite düşük $(p=0.01)$ idi. Bu grupta kitle için sensitivite, PPV ve doğruluk düşük $(p=0.002, p=0.0003$ ve $p=0.001)$ idi.

Cerrahi rezeksiyon öncesi indüksiyon tedavisi alan küçük hücreli dışı akciğer karsinomlu hastalarda PET-BT'nin negatif prediktif değeri ve doğruluğu hafif azalmaktadır. Cerrahi tedavi planlanan akciğer kanserli hastaların değerlendirilmesinde, indüksiyon tedavisi uygulanmış olsa da olmasa da PET-BT faydalı olmaktadır.

Anahtar Kelimeler: Küçük hücreli dışı akciğer karsinomu, positron emisyon tomografisi, akciğer kanseri, cerrahi, yeniden evreleme

\section{INTRODUCTION}

Compared with conventional imaging methods, positron emission tomography-computed tomography (PET-CT) provides more accurate information about primary tumor, lymph node, and metastasis, and it is helpful in initial staging of non-small cell lung carcinoma (NSCLC). In recent years, PET-CT has been increasingly used for the assessment of tumor response in patients treated with chemotherapy and radiotherapy. It provides more reliable results than computed tomography $(\mathrm{CT})$ in the restaging of these patients. Treatment decision based only on morphological features may be misleading in these patients, and PET-CT appears to be a superior noninvasive method as it provides additional metabolic information. Moreover, PET-CT can guide the selection of patients suitable for resection following chemotherapy and radiotherapy. ${ }^{1.5}$

The present study aimed to assess the results of preoperative PET-CT in the primary tumor, parenchymal nodules, and lymph nodes in patients receiving induction therapy due to NSCLC and to compare these results with those surgically treated without receiving preoperative induction therapy.

\section{PATIENTS AND METHODS}

\section{Patient Selection}

Patients who underwent anatomic resection (lobectomy or pneumonectomy) and mediastinal lymph node dissection (MLND) due to NSCLC in 2008 and 2009 and in whom PET-CT was performed for preoperative staging were included in the study. $\mathrm{Pa}-$ tients were evaluated in the following two groups: 1) neoadjuvant group, those who received induction therapy due to stage IIIA and IIIB disease and operated after PET-CT performed; 2) control group, resectable patients with no mediastinal lymph node metastasis who underwent resection following PET-CT assessment without receiving preoperative chemotherapy and/or radiotherapy.

Patients suspected of having or diagnosed with lung cancer were assessed by thoracic CT, bronchoscopy, and PET-CT. Following diagnosis, transbronchial fine-needle aspiration biopsy (FNAB) was initially performed in patients suspected of having N2 disease, which was considered operable, and additional mediastinoscopy or video-assisted thoracoscopic surgery (VATS) was also performed if necessary. Lung resection and MLND were performed through thoracotomy in patients who did not have $\mathrm{N} 2$ disease.

Induction therapy was initiated in lung cancer patients with T4 or N2 disease at baseline. Patients who were noted to have resectable tumor on post-treatment CT and PET-CT but still suspected of having N2 disease were evaluated using transbronchial FNAB, mediastinoscopy or VATS. At baseline, patients who were not suspected of having N2 disease radiologically or patients who were not diagnosed with $\mathrm{N} 2$ disease by invasive and non-invasive methods underwent lung resection and MLND via tho- 
racotomy. All patients were staged according to the staging system proposed by Mountain. ${ }^{6}$

Patients who received preoperative chemotherapy and/or radiotherapy for reasons other than stage IIIA and IIIB disease, those with stage IV disease in the same lung due to reasons other than parenchymal nodule, and those with small cell lung carcinoma, bronchioloalveoler carcinoma or carcinoid tumor were excluded.

\section{Surgical Procedure and Pathological Examination}

Surgical and pathological reports of all patients were retrospectively evaluated and positive and negative lesions were recorded. Primary lesion was recorded as the mass, and the remaining parenchymal lesions were recorded as nodules. Mediastinal lymph nodes were initially grouped as upper N2 (2 and 4), lower $\mathrm{N}_{2}{ }^{7-9}$ and aorticopulmonary (5 and 6) N2 lymph nodes. General N2 disease status was determined according to these results. Right 2, 4, 7, 8, 9, 10, stations and left 5,6, 7, 8, 9, 10 stations and all intrapulmonary lymph stations were evaluated during the MLND procedure. All detected lymph nodes were dissected together with their surrounding fat tissue.

\section{PET-CT Method and Its Assessment}

The integrated PET-CT scan was performed using a dual-modality PET-CT (biograph LSO Duo; Siemens Medical Solutions Inc., Hoffman Estates, IL), consisting of a two-row spiral CT and a fullring lutetium oxy-orthosilicate. All patients fasted for at least 6 hours before the examination. Serum glucose levels were measured and patients with a glucose level of $<200 \mathrm{mg} / \mathrm{dL}$. PET-CT images were obtained 60 minutes after the intravenous administration of fluorodeoxyglucose (FDG) 370-555 MBq. Single-section whole-body spiral CT (50 mAs "Care dose", $110 \mathrm{kV}$, slice thickness $5 \mathrm{~mm}$, table feed $12 \mathrm{~mm} /$ rotation) was then performed. On completion of the CT portion, the PET-CT data (3 minutes/bed position) were acquired in 3-D mode. PET-CT imaging included the entire field of view from the vertex to the proximal thighs.

After the surgical procedure, preoperative PET-CT images of each patient were visually assessed for target lesions by two nuclear medicine specialists blinded to the postoperative pathological staging. Activity clearly above mediastinal background areas was named as positive, whereas activity less than mediastinal background or activity equal to mediastinal background areas was named as negative. PET-CT positive findings that were noted in the areas assessed during surgery were also recorded.

Following the evaluation of lesions by PET-CT and pathological examination as positive or negative, true positive, true negative, false positive and false negative results were recorded. Sensitivity, specificity, positive predictive value (PPV), negative predictive value (NPV), and accuracy were then calculated. The study was approved by the Institutional Review Board Ethics Committee of the Chest Diseases and Thoracic Surgery Training and Research Hospital. Informed consent was obtained from each patient.

\section{Statistical Analysis}

Statistical analysis was performed using the Statistical Package for Social Sciences (SPSS, Inc, Chicago, IL, USA) version 15.0. Descriptive statistics were performed, and the results were expressed as mean \pm standard error for numerical variables and number and percentages for categorical variables. Numerical variables were compared using the Student's t-test. Intergroup comparisons were performed using the chi-square test. The binomial approximation test was used to compare sensitivity, specificity, PPV, NPV, and accuracy of PET-CT between the groups. A p value $<0.05$ was considered statistically significant.

\section{RESULTS}

General and clinical characteristics of the patients are presented in Table 1 . The neoadjuvant group consisted of 58 patients ( 1 female, 57 males) with a mean age of 58.45 \pm 1.1 years (range, 43-77 years). Induction therapy was administered for stage IIIA disease in 18 patients, and for stage IIIB disease in 40 patients. The mean duration between the end of neoadjuvant therapy and PET-CT examination was $33.05 \pm 1.50$ days (range, 17-66 days). Surgery was performed at a mean period of $21.07 \pm 1.55$ days (361 days) after PET-CT examination (Table 2). Although the preliminary diagnosis was NSCLC at ba- 


\begin{tabular}{|c|c|c|c|c|}
\hline Patient Characteristics & $\begin{array}{l}\text { Neoadjuvant Group } \\
\text { n (\%) }\end{array}$ & $\begin{array}{l}\text { Control Group } \\
\text { n (\%) }\end{array}$ & $\begin{array}{l}\text { Total } \\
\text { n (\%) }\end{array}$ & $\mathbf{p}$ \\
\hline Number of patients & $58(26.7)$ & 159 (73.3) & 217 & \\
\hline \multicolumn{5}{|l|}{ Gender } \\
\hline Male & 57 (98.3) & 144 (90.6) & 201 (92.6) & 0.075 \\
\hline Female & $1(1.7)$ & $15(9.4)$ & $16(7.4)$ & \\
\hline \multicolumn{5}{|l|}{ Age } \\
\hline$<60$ years & $33(56.9)$ & $70(44.0)$ & $103(47.4)$ & 0.124 \\
\hline$\geq 60$ years & $25(43.1)$ & $89(56.0)$ & $114(52.6)$ & \\
\hline \multicolumn{5}{|l|}{ Surgical Procedure } \\
\hline Lobectomy & $39(67.2)$ & $131(82.4)$ & $170(78.3)$ & 0.025 \\
\hline Pneumonectomy & 19 (37.8) & $28(17.6)$ & $47(21.7)$ & \\
\hline \multicolumn{5}{|l|}{ Sleeve resection } \\
\hline$(+)$ & $8(13.8)$ & $12(7.5)$ & $20(9.2)$ & 0.186 \\
\hline$(-)$ & $50(86.2)$ & $147(92.5)$ & $197(90.8)$ & \\
\hline \multicolumn{5}{|l|}{ pT } \\
\hline 0 & $8(13.8)$ & 0 & $8(3.7)$ & 0.0001 \\
\hline 1 & $9(15.5)$ & $39(24.5)$ & $48(22.1)$ & \\
\hline 2 & $29(50.0)$ & $90(56.6)$ & $119(54.8)$ & \\
\hline 3 & $10(17.2)$ & $24(15.1)$ & $34(15.7)$ & \\
\hline 4 & $2(3.5)$ & $6(3.8)$ & $8(3.7)$ & \\
\hline \multicolumn{5}{|l|}{$\mathrm{pN}$} \\
\hline 0 & $32(55.2)$ & $119(74.8)$ & $151(69.6)$ & 0.0001 \\
\hline 1 & $10(17.2)$ & $33(20.8)$ & 43 (19.8) & \\
\hline 2 & $16(27.6)$ & $7(4.4)$ & $23(10.6)$ & \\
\hline \multicolumn{5}{|l|}{$\mathrm{pM}$} \\
\hline 0 & 57 (98.3) & $156(98.1)$ & $213(98.2)$ & 1.0 \\
\hline 1 & $1(1.7)$ & $3(1.9)$ & $4(1.8)$ & \\
\hline \multicolumn{5}{|l|}{ pStage } \\
\hline 0 & $7(12.1)$ & 0 & 7 (3.2) & 0.0001 \\
\hline IA & $5(8.6)$ & $31(19.5)$ & 36 (16.6) & \\
\hline IB & $13(22.4)$ & $64(40.3)$ & 77 (35.5) & \\
\hline$\| A$ & $2(3.4)$ & $7(4.4)$ & $9(4.2)$ & \\
\hline IIB & 12 (20.7) & 38 (23.9) & 50 (23.0) & \\
\hline IIIA & $16(27.6)$ & $11(6.9)$ & 27 (12.4) & \\
\hline IIIB & $2(3.5)$ & $5(3.1)$ & 7 (3.2) & \\
\hline IV & $1(1.7)$ & $3(1.9)$ & $4(1.9)$ & \\
\hline \multicolumn{5}{|l|}{ Histology } \\
\hline Squamous & 40 (69.0) & $94(59.1)$ & $134(61.8)$ & 0.01 \\
\hline Adenocarcinoma & $14(24.1)$ & $50(31.5)$ & 64 (29.5) & \\
\hline Large cell & $1(1.7)$ & $11(6.9)$ & $12(5.5)$ & \\
\hline NSCLC & $3(5.2)$ & 0 & $3(1.4)$ & \\
\hline Adenosquamous & 0 & $4(2.5)$ & $4(1.8)$ & \\
\hline \multicolumn{5}{|l|}{ Differentiation } \\
\hline Well & $11(25.6)$ & $33(23.4)$ & $44(23.9)$ & 0.401 \\
\hline Moderate & $22(51.2)$ & $60(42.6)$ & $82(44.6)$ & \\
\hline Poor & 10 (23.2) & 48 (34.0) & 58 (31.5) & \\
\hline
\end{tabular}




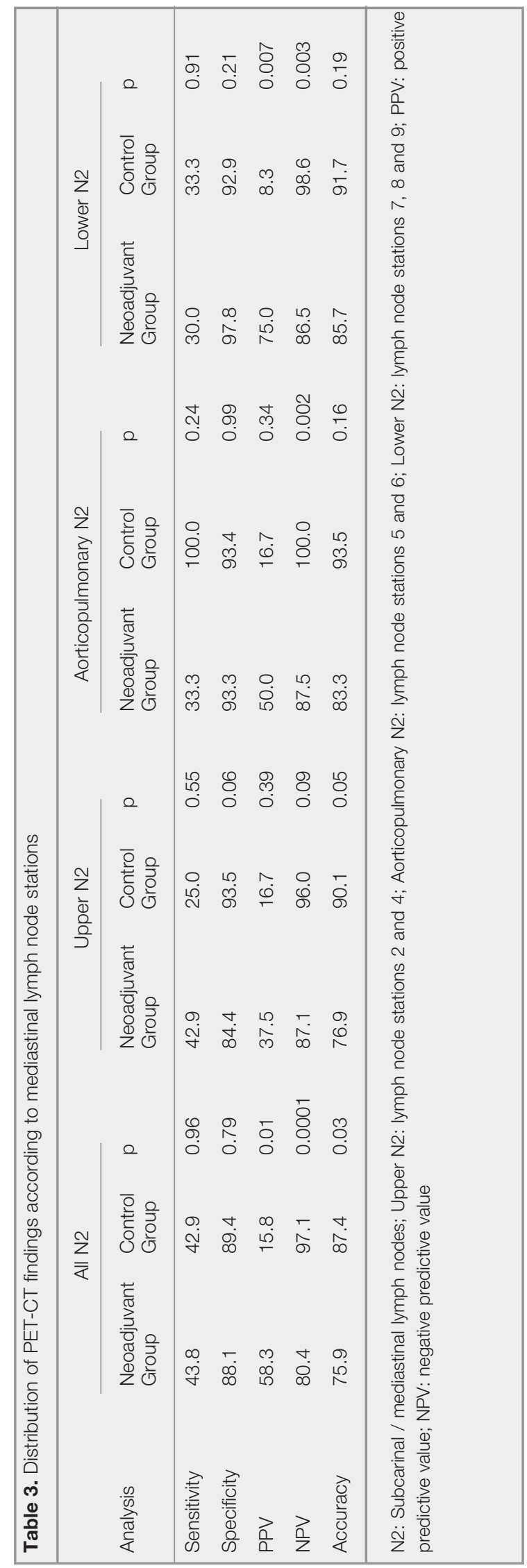

In the patients with N2 lymph nodes, the PPV was significantly higher in the neoadjuvant group than in the control group $(\mathrm{p}=0.01)$, whereas the NPV $(\mathrm{p}=0.0001)$ and accuracy $(\mathrm{p}=0.03)$ were significantly lower. The sensitivity and specificity were similar in these groups. In the patients with aorticopulmonary lymph nodes, the NPV was significantly higher in the control group than that in the neoadjuvant group $(\mathrm{p}=0.002)$, and there were no significant differences between these two groups in terms of other parameters. In the patients with lower N2 lymph nodes, the PPV was higher $(\mathrm{p}=0.007)$ and the NPV was lower $(p=0.003)$ in the neoadjuvant group as compared to the control group. In the patients with N1 lymph nodes, the specificity was found to be lower in the neoadjuvant group $(\mathrm{p}=0.01)$. The sensitivity, PPV and accuracy for mass was lower in the neoadjuvant group $(\mathrm{p}=0.002, \mathrm{p}=0.0003$, and $\mathrm{p}=0.001$, respectively). There were no significant differences between the two groups in terms of the results of the analyses for upper mediastinal N2 disease and nodule (Tables 3 and 4).

\section{DISCUSSION}

Negative results for mediastinal lymph nodes in PET-CT performed for restaging after neoadjuvant therapy in NSCLC should be evaluated with caution. The negative predictive value and accuracy of PET-CT are higher in treatment-naive NSCLC patients. The specificity of PET-CT for N1 disease decreases after induction therapy; the ability of PET-CT to reflect treatment response for these lymph nodes is insufficient. The sensitivity of PETCT decreases once the primary tumor size is reduced by treatment.

PET-CT added to conventional methods of examinations in NSCLC provides a significant impact in the clinical management of these patients. In the staging of NSCLC, PET-CT has a higher diagnostic accuracy than conventional imaging methods, and it is beneficial as a prognostic marker. Based on the information provided by PET-CT, morbidity can be reduced and unnecessary procedures such as thoracotomy can be avoided. Moreover, when compared to other modalities, PET-CT is more helpful in differentiating patients with resectable and non-resectable tumors. ${ }^{7-12}$ 


\begin{tabular}{|c|c|c|c|c|c|c|c|c|c|}
\hline \multirow[t]{2}{*}{ Analysis } & \multicolumn{3}{|c|}{ N1 } & \multicolumn{3}{|c|}{ Mass } & \multicolumn{3}{|c|}{ Nodule } \\
\hline & Neoadjuvant & Control & $p$ & Neoadjuvant & Control & $\mathbf{p}$ & Neoadjuvant & Control & $\mathbf{p}$ \\
\hline Sensitivity & 44.4 & 32.4 & 0.38 & 92.0 & 99.4 & 0.002 & 12.5 & 37.5 & 0.74 \\
\hline Specificity & 80.1 & 94.1 & 0.01 & 50.0 & 0 & 0.34 & 87.5 & 91.9 & 0.69 \\
\hline PPV & 53.3 & 63.2 & 0.56 & 92.0 & 100.0 & 0.0003 & 50.0 & 50.0 & 1.00 \\
\hline NPV & 74.3 & 81.9 & 0.29 & 50.0 & 0 & 0.34 & 87.5 & 87.2 & 0.98 \\
\hline Accuracy & 68.5 & 79.6 & 0.09 & 86.2 & 99.4 & 0.001 & 80.0 & 82.2 & 0.86 \\
\hline
\end{tabular}

As PET-CT helps in more accurate mediastinal staging, it allows better patient selection. However, patients may also be misdiagnosed with $\mathrm{N} 2$ disease due to false-positive lymph nodes. A tissue biopsy should be performed on the area with positive PETCT result for accurate staging. ${ }^{11-14}$ In the present study, the PPV of PET-CT in the staging of mediastinal/subcarinal (N2) lymph nodes was lower than those reported previously (16\%). This might be due to the presence of lymph nodes affected by tuberculosis or sarcoidosis. In parallel with the previous studies $^{8,13}$, the results determined for N1 disease was lower compared to those determined for mediastinal disease. We believe that this is acceptable, as treatment type is not much affected in N1 disease.

Gonzalez-Stawinski et al. ${ }^{15}$ suggested that PET-CT neither confirmed nor excluded mediastinal involvement in NSCLC and that cervical mediastinoscopy with lymph node biopsy remained to be the criterion standard for mediastinal staging. Verhagen et al. ${ }^{16}$ reported that PET-CT reduced the need for mandatory mediastinoscopy by $46 \%$ without increasing the risk for unexpected N2 involvement at thoracotomy. General opinion is that high NPV of PET-CT in mediastinal staging may reduce the need for invasive mediastinal staging..$^{12,14,17-19}$ In the present study, N2 disease was noted only in approximately $3 \%$ of PET-CT negative patients.

Conventional imaging methods provide information regarding the appearance of the tumor and the relationship of the tumor to surrounding structures following chemotherapy/radiotherapy. However, this may also be associated with some problems.
Firstly, there may still be resistant cell clones despite significant regression of the tumor following chemotherapy/radiotherapy. Secondly, the residual mass may be completely necrotic. In these types of lesions, PET-CT is capable of providing greater metabolic information than the anatomic information acquired by conventional methods. ${ }^{2}$ The principal prognostic indicator for patients treated surgically following chemotherapy/radiotherapy is the presence or absence of mediastinal disease $(\mathrm{N} 2)^{20-23}$ Although Port et al. ${ }^{24}$ reported that PET-CT had limited accuracy in determining primary tumor response and extent of nodal disease following induction chemotherapy in NSCLC, Eschmann et al. ${ }^{2}$ and Hellwig et al. ${ }^{3}$ suggested that mediastinoscopy might be omitted in PET-CT negative patients due to the high NPV of PET-CT following induction therapy. Cerfolio et al. ${ }^{25}$ reported that PET-CT was superior in determining the presence or absence of residual tumor at the primary site and in the paratracheal N2 lymph nodes.

PET-CT has a high potential for accuracy in determining $\mathrm{T}$ and $\mathrm{N}$ status in NSCLC patients receiving induction chemotherapy and/or radiotherapy ${ }^{25,26}$ Concerning the evaluation of $\mathrm{T}$ status, however, the efficacy of PET-CT is limited in the assessment of $\mathrm{T} 2$ and $\mathrm{T} 3$ lesions or especially small satellite T4 lesions in the same lobe. ${ }^{25}$ In the present study, while the NPV of PET-CT was approximately $87 \%$ in detecting ipsilateral nodules in both groups, the PPV remained around 50\%. In other words, PET$\mathrm{CT}$ is highly capable of detecting the absence of the nodule. Metastatic nodule was found to be actually present in half of the patients who were noted to ha- 
ve metastatic nodule on PET-CT. We also found in the present study that tumor was present in half of the patients who received preoperative chemotherapy/radiotherapy and in whom no viable tumor was detected on PET-CT, whereas no tumors were detected in $8 \%$ of the patients who had positive results on PET-CT.

PET-CT positive lesions noted after induction therapy require histological confirmation due to the low PPV of PET-CT especially in lymph nodes, as observed in our study. ${ }^{1}$ In addition, invasive surgical procedures may be omitted in PET-CT negative resectable lesions based on the NPV of over $80 \%$. Reduction of FDG uptake on control PET-CT performed after induction therapy has a highly decisive effect on the patient outcome..$^{1-4,21,27}$ However, survival analysis together with additional examinations of these lesions will provide better insight in terms of patient outcome. In the light of these findings, PET-CT following induction therapy is currently considered a helpful tool in determining the modality of treatment. ${ }^{1-4}$

When two groups were compared, the NPV and accuracy of PET-CT in detecting N2 disease were found to be significantly lower in the neoadjuvant group. Therefore, PET-CT negativity should be questioned more rigorously in these patients compared to those not receiving preoperative therapy, and further invasive staging methods need to be utilized. When the lymph node groups were compared, results were noted to be similar for upper N2 lymph nodes, whereas the NPV was significantly reduced in the neoadjuvant group for aorticopulmonary and lower N2 lymph nodes. While the ability to detect the primary tumor was $100 \%$ in the treatment-naive group, it was noted to be $92 \%$ in the group receiving preoperative induction therapy. However, in the neoadjuvant group, half of the patients with no viable tumor were found to be PET-CT positive. The results for detecting nodules other than the primary tumor and N1 disease in the ipsilateral lung were similar in both groups. The PPV in N2 disease was higher in neoadjuvant group (58.3\%) than control group (15.8\%). In control group, the cause of lower PPV in N2 disease may be the frequency of granulomatous infection in our country. The exclusion of these granulomatous infections in neoad- juvant group might cause higher PPV in N2 disease.

Although two groups were not similar in terms of clinical stages, our aim was to compare the PET-CT results between patients receiving chemotherapy and/or radiotherapy or not. All patients in both groups were decided to be suitable for surgery, had preoperative PET-CT examinations, were assessed by the same nuclear medicine specialists using the same PET-CT device, and were operated by the same surgical team. To the best of our knowledge, there have been no previous studies satisfying all of these conditions.

Negative PET-CT results for mediastinal lymph nodes during preoperative restaging following neoadjuvant therapy should be evaluated with caution. However, the high NPV of over $80 \%$ suggests that PET-CT should not be completely ruled out. Moreover, the high NPV in treatment-naive NSCLC patients positively affects the accuracy of PET-CT in these patients.

The specificity of PET-CT for N1 disease decreases during the restaging following induction therapy. This suggests that PET-CT is insufficient to demonstrate treatment response for these lymph nodes. Moreover, the sensitivity of PET-CT also decreases due to the potential reduction of tumor cell metabolism resulted from the decrease in the primary tumor size after treatment.

What is expected of PET-CT is to determine the accurate stage of the disease and to manage the optimum therapy. PET-CT after chemotherapy and/or radiotherapy is reported to be better than $\mathrm{CT}$ in assessment of treatment response. However, PET-CT may be deficient in determining live tumor cells because of existence of necrosis, fibrosis in tumor tissue and the presence of small sized lesions after treatment. In our study, NPV and accuracy in N2 disease, the most important predictive factor in consideration of disease and surgical treatment, were significantly low in neoadjuvant group. As pathologies which may cause false positivity in neoadjuvant group such as granulomatous infection had been eliminated, PPV was higher in assessment of N2 disease.

In conclusion, although the NPV and accuracy of PET-CT slightly decreased in NSCLC patients re- 
ceiving induction therapy before surgical resection, PET-CT appears to be beneficial for the assessment of patients who will be treated surgically for NSCLC whether they have received induction therapy or not.

\section{REFERENCES}

1. Cerfolio RJ, Bryant AS, Ojha B. Restaging patients with N2 (stage Illa) non-small cell lung cancer after neoadjuvant chemoradiotherapy: A prospective study. J Thorac Cardiovasc Surg 131: 1229-1235, 2006.

2. Eschmann SM, Friedel G, Paulsen F, et al. Repeat 18F-FDG PET-CT for monitoring neoadjuvant chemotherapy in patients with stage III non-small cell lung cancer. Lung Cancer 55: 165-171, 2007.

3. Hellwig D, Graeter TP, Ukena D, et al. Value of F-18fluorodeoxyglucose positron emission tomography after induction therapy of locally advanced bronchogenic carcinoma. J Thorac Cardiovasc Surg 128: 892899, 2004.

4. Eschmann SM, Friedel G, Paulsen F, et al. 18F-FDG PET-CT for assessment of therapy response and preoperative re-evaluation after neoadjuvant radio-chemotherapy in stage III non-small cell lung cancer. Eur J Nucl Med Mol Imaging 34: 463-471, 2007.

5. Cerfolio RJ, Ojha B, Bryant AS, et al. The accuracy of integrated PET-CT compared with dedicated PET-CT alone for the staging of patients with non-small cell lung cancer. Ann Thorac Surg 78: 1017-1023, 2004.

6. Mountain CF. Revisions in the International System for Staging Lung Cancer. Chest 111: 1710-1717, 1997.

7. Abea K, Baba S, Kanekoa K, et al. Diagnostic and prognostic values of FDG-PET-CT in patients with non-small cell lung cancer. Clinical Imaging 33: 90-95, 2009.

8. Subedi N, Scarsbrook A, Darby M, et al. The clinical impact of integrated FDG PET-CT on management decisions in patients with lung cancer. Lung Cancer 64: 301-307, 2009.

9. Yanga W, Fub Z, Yuc J, et al. Value of PET-BT/CT versus enhanced CT for locoregional lymph nodes in nonsmall cell lung cancer. Lung Cancer 61: 35-43, 2008.

10. Franzius C. FDG PET: advantages for staging the mediastinum? Lung Cancer 45 (Suppl 2): S69-S74, 2004.

11. Reed CE, Harpole DH, Posther KE, et al. American College of Surgeons Oncology Group Z0050 trial. Results of the American College of Surgeons Oncology Group Z0050 trial: the utility of positron emission tomography in staging potentially operable non-small cell lung cancer. J Thorac Cardiovasc Surg 126: 19431951, 2003.

12. Passlick B. Mediastinal staging (take home messages). Lung Cancer 45 (Suppl 2): S85-S87, 2004.
13. Cerfolio RJ, Ojha B, Bryant AS, et al. The Role of FDGPET scan in staging patients with nonsmall cell carcinoma. Ann Thorac Surg 76: 861-866, 2003.

14. Graeter TP, Hellwig D, Hoffmann K, et al. Mediastinal lymph node staging in suspected lung cancer: comparison of positron emission tomography with $\mathrm{F}$-18-fluorodeoxyglucose and mediastinoscopy. Ann Thorac Surg 75: 231-235, 2003.

15. Gonzalez-Stawinski GV, Lemaire A, Merchant F, et al. A comparative analysis of positron emission tomography and mediastinoscopy in staging non-small cell lung cancer. J Thorac Cardiovasc Surg 126: 19001905, 2003.

16. Verhagen AF, Bootsma GP, Tjan-Heijnen VC, et al. FDG-PET in staging lung cancer: how does it change the algorithm? Lung Cancer 44: 175-181, 2004.

17. Vansteenkiste JF, Stroobants SG, De Leyn PR, et al. Lymph node staging in non-small-cell lung cancer with FDG-PET scan: a prospective study on 690 lymph node stations from 68 patients. J Clin Oncol 16: 21422149, 1998.

18. Perigaud C, Bridji B, Roussel JC, et al. Prospective preoperative mediastinal lymph node staging by integrated positron emission tomography-computerised tomography in patients with non-small-cell lung cancer. Eur J Cardiothorac Surg 36: 731-6, 2009.

19. Vansteenkiste JF. PET scan in the staging of non-small cell lung cancer. Lung Cancer 42: S27-S37, 2003.

20. Surmont V, van Klaveren RJ, Goor C, et al. Lessons to learn from EORTC study 08981: A feasibility study of induction chemoradiotherapy followed by surgical resection for stage IIIB non-small cell lung cancer. Lung Cancer 55: 95-99, 2007.

21. Hoekstra CJ, Stroobants SG, Hoekstra OS, et al. The value of [18F] fluoro-2-deoxy-D-glucose positron emission tomography in the selection of patients with stage IIIA-N2 non-small cell lung cancer for combined modality treatment. Lung Cancer 39: 151-157, 2003.

22. Voltolini L, Luzzi L, Ghiribelli C, et al. Results of induction chemotherapy followed by surgical resection in patients with stage IIIA (N2) non-small cell lung cancer: the importance of the nodal down-staging after chemotherapy. Eur J Cardiothorac Surg 20: 1106-1112, 2001.

23. Vansteenkiste J, De Leyn P, Deneffe G, et al. Present status of induction treatment in stage IIIA-N2 nonsmall cell lung cancer: a review. The Leuven Lung Cancer Group. Eur J Cardiothorac Surg 13: 1-12, 1998.

24. Port JL, Kent MS, Korst RJ, et al. Positron emission tomography scanning poorly predicts response to preoperative chemotherapy in non-small cell lung cancer. Ann Thorac Surg 77: 254-259, 2004.

25. Cerfolio RJ, Ojha B, Mukherjee S, et al. Positron emission tomography scanning with 2-fluoro-2- deoxy-Dglucose as a predictor of response of neoadjuvant treatment for non-small cell carcinoma. J Thorac Cardiovasc Surg 125: 938-944, 2003. 
26. Yamamoto $Y$, Nishiyama $Y$, Monden $T$, et al. Correlation of FDG-PET-CT findings with histopathology in the assessment of response to induction chemoradiotherapy in non-small cell lung cancer. Eur J Nucl Med Mol Imaging 33: 140-147, 2006.

27. Pottgen C, Levegrun S, Theegarten D, et al. Value of 18F-fluoro-2-deoxy-D-glucose-positron emission tomography/computed tomography in non-small-cell lung cancer for prediction of pathologic response and times to relapse after neoadjuvant chemoradiotherapy. Clin Cancer Res 12: 97-106, 2006.

\section{Correspondence}

Dr. Ahmet Emin ERBAYCU

İzmir Göğüs Hastalıkları ve Cerrahisi Eğitim

ve Araştırma Hastanesi

Göğüs Hastalıkları Bölümü

35110 Yenişehir

IZMIR / TURKEY

Tel: (+90.232) 4330796

Fax:(+090.232) 4587262

e-mail:drerbaycu@yahoo.com 